\title{
The Window of Risk for Emigration of Wheat streak mosaic virus Varies with Host Eradication Method
}

\author{
W. Jiang and K. A. Garrett, Department of Plant Pathology, Kansas State University, Manhattan 66506; \\ D. E. Peterson, Department of Agronomy, Kansas State University, Manhattan 66506; T. L. Harvey, Department of \\ Entomology, Kansas State University, Manhattan 66506; R. L. Bowden, USDA-ARS, Plant Science and Entomol- \\ ogy Research Unit, 4008 Throckmorton Hall, Kansas State University, Manhattan 66506; and L. Fang, Department \\ of Plant Pathology, Kansas State University, Manhattan 66506
}

\begin{abstract}
Jiang, W., Garrett, K. A., Peterson, D. E., Harvey, T. L., Bowden, R. L., and Fang, L. 2005. The window of risk for emigration of Wheat streak mosaic virus varies with host eradication method. Plant Dis. 89:853-858.

The wheat curl mite (WCM), Aceria tosichella, the vector of Wheat streak mosaic virus (WSMV), often survives the summer on volunteer wheat (Triticum aestivum) and may disperse from this "green bridge" in fall to newly planted winter wheat. Because some methods for managing volunteer wheat do not directly kill WCM, there is a window of risk for WCM and WSMV emigration after management has been applied. WCM survival in response to treatment of wheat by glyphosate, paraquat, stem cutting, and withholding water was measured in greenhouse experiments to determine how this window of risk for emigration varies with management. WCM populations on plants treated with paraquat or stem cutting decreased from the beginning of the sampling period. WCM populations on plants treated with glyphosate or that received no water increased up to 3 days after application and then decreased by 10 days after application. If glyphosate is used to manage volunteer wheat infested with WCM, it should be applied well before wheat is planted in fall. WCM in declining populations tended to be in an upright posture that could facilitate emigration via wind. The total green leaf area was strongly correlated with the number of WCM for treated plants and could be used in the field to predict the posttreatment survival of mites that pose a risk of emigration.
\end{abstract}

Seasonal or local eradication of the host is sometimes an option for management of a disease or disease vector. For wheat stem rust, the complete eradication of an alternate host has been attempted (23). For citrus canker, estimates of critical areas around infection sources have been used to guide local eradication of all host species to prevent disease spread $(9,10)$. For annual crop species, seasonal eradication of a host species is a possibility in limited areas adjacent to future crop plantings. This option may be particularly relevant to winter annual crops that do not grow during the summer when many vectors may be most active. In winter wheat (Triticum aestivum), the "green bridge" provided by volunteer wheat growing in summer is important to maintaining the life cycle of several pathogens and insect pests, including the take-all pathogen, leaf and stem rust fungi, Barley yellow dwarf virus, Hessian fly, and the Russian wheat aphid (1). If volunteer wheat can be eradicated from

Corresponding author: K. A. Garrett

E-mail: kgarrett@ksu.edu

Accepted for publication 21 March 2005.

DOI: 10.1094/PD-89-0853

(C) 2005 The American Phytopathological Society a large enough area around new wheat plantings, the risk of disease and pest transmission to the new wheat may be substantially reduced, particularly if other host species are also uncommon.

Volunteer wheat is also important for maintaining populations of Wheat streak mosaic virus (WSMV), an important pathogen of winter wheat in the United States and Canada that is vectored by the wheat curl mite (WCM), Aceria tosichella Keifer (26). Volunteer wheat emerging before or immediately after harvest is a primary source of inoculum for wheat planted in the fall $(29,30)$. Since the WCM can only survive 4 to 6 days without a green host (26), destroying volunteer wheat 2 weeks before planting is recommended to reduce the probability of WSM infection $(1,33)$. Volunteer wheat may be destroyed by tillage or the application of herbicides. Glyphosate (Roundup) (6) or paraquat (Gramoxone or Cyclone) (16) are often used for destroying volunteer wheat in the summer. There is no evidence or reason to believe that the herbicides have a direct effect on the WCM, but destroying volunteer wheat forces the WCM to find another host.

Important questions remain about the effect of volunteer wheat management on WSMV and WCM populations, particularly about the effect of the timing of treatments on WCM survival and potential movement to newly planted wheat. The primary objective of these experiments was to determine the effect of glyphosate, paraquat, stem cutting, and withholding water on WCM survival, position on wheat plants, and WCM readiness to leave plants (as measured by their posture) over time. WCM are capable of holding their bodies perpendicular to the leaf surface (18), a behavior that could enhance their wind dispersal. Two secondary objectives were to determine how the effect of herbicide differed for diseased and nondiseased plants and to determine the relationship between green leaf area and WCM population size. This new information can be used to improve decisions concerning the timing of management of volunteer wheat and WSM.

\section{MATERIALS AND METHODS}

WCM and WSMV maintenance and transfer methods. A viruliferous strain of the WCM previously studied by Harvey et al. (15) was used in all experiments. The WCM colony was maintained on the WSM-susceptible wheat cultivar Tomahawk, selected because of its clear symptom expression in response to WSMV infection. When the WCM colony was introduced to healthy 'Tomahawk' plants, the plants developed typical symptoms of WSMV, and an indirect enzyme-linked immunosorbent assay was performed to confirm the presence of WSMV in the diseased plants, as described by Christian and Willis (3). The absorbance values observed for the infested plants were at least two times those of the equivalent uninfested control.

As plants used to maintain the colony declined, heavily infested leaves were cut off and hairclips were temporarily used to attach them to two- or three-leaf stage healthy plants to transfer viruliferous WCM. After 3 to 4 weeks, the newly infested plants were used as a source to infest the new two- or three-leaf stage healthy plants for the experiments (11). Infested leaf clippings about $1 \mathrm{~cm}$ long were used to infest the experimental wheat plants. To introduce roughly the same number of WCM (generally 20 to 40 ) to each plant, a leaf clipping was placed in the whorl of one plant (near the growing 
point) at the two-leaf stage in each pot of four plants. During maintenance of the WCM colony and during the experiments, the temperature in the greenhouse was maintained at approximately $26^{\circ} \mathrm{C}$ in the daytime and $22^{\circ} \mathrm{C}$ at night with a 16 -h day length. Experimental treatments were applied to plants approximately 3 weeks after WCM infestation.

Experimental treatments. Two "tillage-drought experiments" were performed, each with a randomized complete block design with three blocks. In the first experiment, WCM responses were observed over 7 days, and in the second over 15 days. Sampling for WCM analysis was destructive, so different pots were sampled at each sampling date in all experiments. The tillage-drought experiments included two treatments at the extremes of the level of water stress plants might experience due to tillage or drought, in comparison with control plants that received no treatments. The "no water" treatment represented a chronic water stress with plants receiving no water after the experiment was initiated. Stem cutting represented an extreme water deprivation treatment, with the upper plant parts cut off near the soil with scissors and held in place with tape. The stress experienced by volunteer wheat after tillage would probably fall somewhere between these two treatments. After the treatments were applied in these and the herbicide experiment, the plants were watered every other day, with the exception of the no water treatment.

The "herbicide experiment" included 10 blocks, with five blocks run at one time and the other five run approximately 1 month later. For all blocks, the population of WCM and the response of plants were observed over 15 days. The two herbicide treatments were compared with an untreated control. One herbicide treatment consisted of a single application of glyphosate (Roundup Ultra Max + ammonium sulfate) and the other of a single application of paraquat (Gramoxone Max + nonionic surfactant), each applied at the rate of $0.56 \mathrm{lb}$ a.i./acre (627.7 $\mathrm{g}$ a.i./ha).

Sampling methods. Total WCM counts were collected for distinct pots at each sampling date. Each WCM was also designated as living or not based on whether it could be observed to move and whether it had typical healthy coloration. Motionless mites that appeared otherwise healthy were

Table 1. Mean number of living wheat curl mites per plant over time in two tillage-drought experiments $^{2}$

\begin{tabular}{|c|c|c|c|c|c|}
\hline \multirow[b]{2}{*}{ Treatment } & \multicolumn{5}{|c|}{ Days after treatment } \\
\hline & 1 & 2 & 3 & 5 & 7 \\
\hline \multicolumn{6}{|c|}{ First tillage-drought experiment } \\
\hline Stem cutting & $115.33^{\mathrm{a}}$ & $129.67^{\mathrm{a}}$ & $67.67^{\mathrm{ab}}$ & $2.33^{\mathrm{bc}}$ & $0.00^{c} \mathrm{y}$ \\
\hline No water & 85.67 & 155.33 & 126.67 & $119.33_{\mathrm{x}}$ & 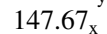 \\
\hline \multirow[t]{2}{*}{ Control } & $59.67^{\mathrm{b}}$ & $158.33^{\mathrm{ab}}$ & $89.67^{\mathrm{ab}}$ & $222.67^{a}{ }_{x}$ & $265.33^{a}{ }_{x}$ \\
\hline & 1 & 3 & 6 & 10 & 15 \\
\hline \multicolumn{6}{|c|}{ Second tillage-drought experiment } \\
\hline $\begin{array}{l}\text { Stem cutting } \\
\text { No water } \\
\text { Control }\end{array}$ & $\begin{array}{l}159.00^{\mathrm{a}} \\
174.67^{\mathrm{a}} \\
170.67^{\mathrm{b}}\end{array}$ & $\begin{array}{r}5.00^{\mathrm{b}}{ }_{\mathrm{y}} \\
131.00^{\mathrm{b}}{ }_{\mathrm{x}} \\
190.00^{\mathrm{b}}{ }_{\mathrm{x}}\end{array}$ & $\begin{array}{r}2.67^{\mathrm{bc}}{ }_{\mathrm{y}} \\
93.33^{\mathrm{c}}{ }^{\mathrm{x}} \\
172.67^{\mathrm{b}} \mathrm{x}\end{array}$ & $\begin{array}{r}2.00^{\mathrm{bc}}{ }_{\mathrm{y}} \\
3.00^{\mathrm{d}} \mathrm{y}^{\mathrm{y}} \\
406.00^{\mathrm{a}} \mathrm{x}\end{array}$ & $\begin{array}{r}0.00^{\mathrm{c}} \mathrm{y} \\
0.33^{\mathrm{d}^{\mathrm{y}}} \\
242.00^{\mathrm{b}}{ }_{\mathrm{x}}\end{array}$ \\
\hline
\end{tabular}

${ }^{\mathrm{z}}$ Within each experiment, superscripts $\mathrm{a}, \mathrm{b}$, or $\mathrm{c}$ indicate means in a row (time course within a treatment) that group separately $(P<0.05)$ following an analysis of variance; within each experiment, subscripts $\mathrm{x}, \mathrm{y}$, and $\mathrm{z}$ indicate means that group separately in a column (comparison of treatment effects at a time point). If there were no significant differences in a row or column, the super- or subscripts are not shown.

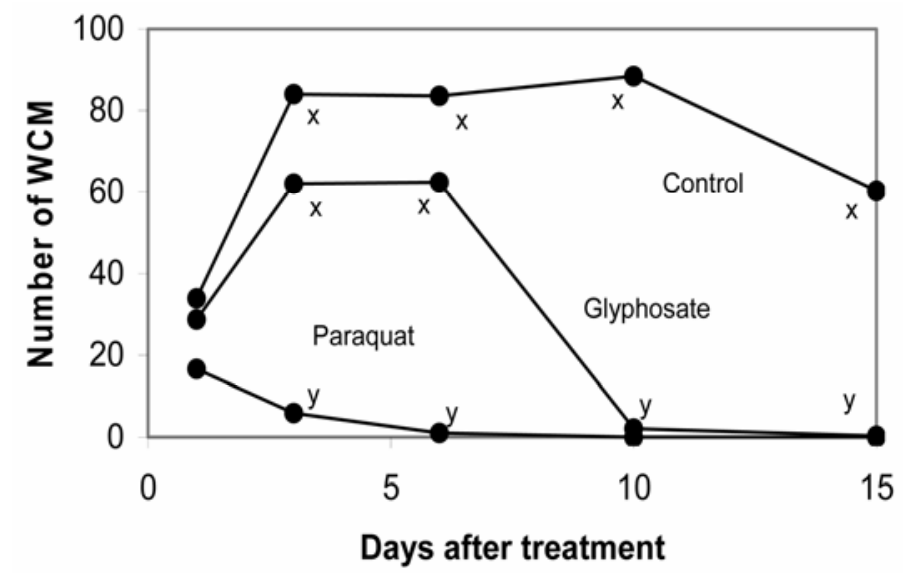

Fig. 1. Number of wheat curl mites (WCM) over time in response to herbicide treatments. Significantly different $(P<0.05)$ population sizes within a date are indicated by different letters. prodded and monitored for movement. For each plant sampled, counts were made for adaxial and abaxial leaf surfaces and for the upper and lower halves of leaves for each of the youngest three leaves. Because of the leaf curling caused by WCM feeding, it was clear which was the "inside" part of a leaf. Each sampling day, plants were moved from the greenhouse to the lab and leaves were detached from plants just prior to counting mites. Leaves were gently unrolled so that the WCM outside the leaves could be observed and counted and then leaves were attached to sticky tape inside a 10 -cm-diameter petri dish to facilitate counting. The WCM were counted using a dissecting microscope at $\times 20$ magnification and a fiber optic system to provide cold light in order to reduce handling effects on WCM. The posture of the WCM, in the sense of whether they were in a position parallel to the leaf or perpendicular (upright), was also noted. In the herbicide experiment, total green leaf area (TGLA) for the three youngest leaves was estimated by multiplying leaf width by leaf length and by a visual estimate of the proportion of green leaf area.

Statistical analysis. In our analysis of WCM populations, we evaluated the treatment effects in terms of when treated populations were smaller than control populations. We also determined the number of days after treatment application required for the estimated WCM population to go below a mean of one WCM per plant. To test for significant differences between treatments over time, we applied a mixed model with high and low variance classes $(7,17)$ using SAS Proc Mixed (SAS Institute, Cary, NC). In addition, populations were log-transformed and percentages were arcsine square root transformed to more closely match the assumptions of an analysis of variance (36). The correlation between TGLA and the number of living WCM was estimated by considering all sampling dates and treatments in the herbicide experiment.

\section{RESULTS}

Results are presented in terms of the populations of WCM that were designated as living unless otherwise indicated.

Number of living WCM per plant. Populations of WCM on control plants in all three experiments increased from the beginning of the sampling interval, with a trend toward reduced population sizes by the fifteenth day after treatments were applied (Table 1, Fig. 1). Stem cutting resulted in WCM populations significantly lower than the control by the fifth day in the first experiment and by the third day in the second experiment (Table 1). For stem cutting, the estimate of WCM population size per plant was less than one by the seventh day in the first experiment and by the fifteenth day in the second experiment (Table 1). Withholding water resulted in 
WCM populations significantly lower than the control by the tenth day in the second experiment (Table 1), with the estimate of WCM population size per plant less than one by the fifteenth day in the second experiment (Table 1). In the herbicide experiment, WCM populations were significantly lower than on control plants by the third day for the paraquat treatment and by the tenth day for the glyphosate treatment (Fig. 1). The estimate of WCM population size per plant was less than one by the tenth day for the paraquat treatment and by the fifteenth day for the glyphosate treatment (Fig. 1).

Percentage of WCM that were designated living. For control plants, the percentage of WCM that were living changed significantly over time only in the second tillage-drought experiment, and then only a small change was observed in the middle of the sampling period (Table 2). Stem cutting resulted in a significantly lower percent WCM living than for the control plants by the fifth day after treatment in the first experiment and by the sixth day after treatment in the second experiment (Table 2). For stem cutting, the estimated percent WCM that were living went below $5 \%$ by the fifth day after treatment in the first experiment and by the tenth day after treatment in the second experiment (Table 2). Withholding water resulted in a significantly lower percent WCM living than for the control plants by tenth day in the second experiment (Table 2). For the no water treatment, the estimated percent WCM that were living went below $5 \%$ by the tenth day in the second experiment (Table 2). In the herbicide experiment, the percent WCM living was lower than for control plants by the third day after treatment with paraquat and by the tenth day after treatment with glyphosate (Table 2). The estimated percentage of WCM that were living went below 5\% for paraquat by the sixth day and for glyphosate by the fifteenth day (Table 2).

Percentage of WCM on the third leaf. The percentage of living WCM on the third leaf, as opposed to the second or first leaf, changed significantly on control plants only during the middle of the sampling period in the second experiment (Table 3). For stem cutting, the estimated percentage on the third leaf was significantly different from the control plants only in the second experiment at 6 and 10 days after treatment. The estimated percentage on stem-cut plants on these dates was based on a small number of mites (Table 1) and changed from $0 \%$ after 6 days to $100 \%$ after 10 days (Table 3 ). For the no water treatment, the percent WCM on the third leaf was significantly lower than on control plants on the tenth and fifteenth sampling dates (Table 3). In the herbicide experiment, the percent WCM on the third leaf was significantly higher on paraquat-treated plants than on control plants throughout the sampling period
(Table 3). The percentage was higher for glyphosate-treated plants only on the tenth day after treatment (Table 3).

Percentage of WCM in an upright posture. On control plants, the percentage of living WCM in an upright posture did not exhibit clear trends, although it did vary significantly over time in the second experiment (Table 4). Stem cutting resulted in a significantly higher percent WCM in an upright position over most of the sampling periods (Table 4). Withholding water produced a higher percentage in an upright position on the tenth day after treatment in the second experiment (Table 4). In the herbicide experiment, there was a nonsignificant trend toward a higher percentage in an upright position for the gly- phosate treatment in the later days of sampling (Table 4).

Percentage of WCM on upper half of leaves. The percentage of living WCM on control plants that were on the upper half of leaves (i.e., toward the leaf tip) never varied significantly over the sampling periods of the three experiments (Table 5). Stem cutting resulted in a significantly reduced percent WCM on the upper half of the leaf compared with control plants beginning 2 days after treatment in the first experiment, but in the second experiment the small WCM populations (Table 1) showed a rapid change from 100 to $0 \%$ (Table 5). Withholding water sometimes resulted in a significantly increased percentage on the upper half of the leaf com-

Table 2. Mean percentage of wheat curl mites alive over time in two tillage-drought experiments and one herbicide experiment ${ }^{2}$

\begin{tabular}{|c|c|c|c|c|c|}
\hline \multirow[b]{2}{*}{ Treatment } & \multicolumn{5}{|c|}{ Days after treatment } \\
\hline & 1 & 2 & 3 & 5 & 7 \\
\hline \multicolumn{6}{|c|}{ First tillage-drought experiment } \\
\hline Stem cutting & $31.01^{\mathrm{a}}$ & $30.32^{\mathrm{a}}$ & $36.22^{\mathrm{a}}{ }_{\mathrm{x}}$ & $4.48^{\mathrm{b}} \mathrm{y}$ & $0.00^{\mathrm{b}}$ \\
\hline No water & $20.37^{\mathrm{b}}$ & $31.94^{\mathrm{a}}$ & $15.89^{\mathrm{b}} \mathrm{y}$ & $28.99^{a}{ }^{a}$ & $29.86^{a}{ }_{x}^{a}$ \\
\hline \multirow[t]{2}{*}{ Control } & 18.29 & 25.63 & $24.81_{x y}$ & $28.10_{x}^{x}$ & $26.40_{x}^{x}$ \\
\hline & 1 & 3 & 6 & 10 & 15 \\
\hline \multicolumn{6}{|c|}{ Second tillage-drought experiment } \\
\hline Stem cutting & $34.44^{\mathrm{a}}$ & $17.49^{\mathrm{b}}$ & $8.60^{\mathrm{bc}}$ & $4.08^{b c}$ & $0.00^{c}{ }_{y}$ \\
\hline No water & $29.66^{\mathrm{a}}$ & $23.81^{\mathrm{a}}$ & $24.97^{a}{ }_{x}^{3}$ & $1.05^{\mathrm{b}}{ }_{\mathrm{y}}^{\mathrm{g}}$ & $0.79^{\mathrm{b}} \mathrm{y}$ \\
\hline \multirow[t]{2}{*}{ Control } & $27.69^{\mathrm{ab}}$ & $33.42^{\mathrm{ab}}$ & $23.24^{\mathrm{b}}{ }_{\mathrm{x}}^{\mathrm{a}}$ & $34.46^{a}{ }_{x}^{a}$ & $27.40^{a b}$ \\
\hline & 1 & 3 & 6 & 10 & 15 \\
\hline \multicolumn{6}{|c|}{ Herbicide experiment } \\
\hline Paraquat & $40.55^{\mathrm{a}}$ & $18.01^{\mathrm{a}} \mathrm{y}$ & $3.66_{\mathrm{y}}^{\mathrm{b}}$ & $0.00_{\mathrm{y}}^{\mathrm{b}}$ & $0.00^{\mathrm{b}}$ \\
\hline Glyphosate & $34.66^{\mathrm{a}}$ & $38.36^{a}{ }_{x}$ & $32.63^{3}{ }_{x}$ & $14.24_{\mathrm{y}}^{\mathrm{b}}$ & $3.34_{\mathrm{y}}^{\mathrm{b}}$ \\
\hline Control & 41.75 & $37.27^{\wedge}$ & $34.62^{x}$ & $30.79_{x}$ & $32.92_{\mathrm{x}}$ \\
\hline
\end{tabular}

${ }^{\mathrm{z}}$ Within each experiment, superscripts $\mathrm{a}, \mathrm{b}$, or $\mathrm{c}$ indicate means in a row (time course within a treatment) that group separately $(P<0.05)$ following an analysis of variance; within each experiment, subscripts $\mathrm{x}, \mathrm{y}$, and $\mathrm{z}$ indicate means that group separately in a column (comparison of treatment effects at a time point). If there were no significant differences in a row or column, the super- or subscripts are not shown.

Table 3. Mean percentage of living wheat curl mites on the third leaf, as opposed to the first and second leaves, over time in two tillage-drought experiments and one herbicide experiment ${ }^{2}$

\begin{tabular}{|c|c|c|c|c|c|}
\hline \multirow[b]{2}{*}{ Treatment } & \multicolumn{5}{|c|}{ Days after treatment } \\
\hline & 1 & 2 & 3 & 5 & 7 \\
\hline \multicolumn{6}{|c|}{ First tillage-drought experiment } \\
\hline Stem cutting & 38.89 & 46.78 & 35.05 & 33.33 & - \\
\hline No water & 40.48 & 38.73 & 32.15 & 49.01 & 55.00 \\
\hline \multirow[t]{2}{*}{ Control } & 43.33 & 29.50 & 46.32 & 27.63 & 26.70 \\
\hline & 1 & 3 & 6 & 10 & 15 \\
\hline \multicolumn{6}{|c|}{ Second tillage-drought experiment } \\
\hline Stem cutting & $43.36^{\mathrm{b}}$ & $25.76^{\mathrm{b}}$ & $0.00^{c}{ }_{\mathrm{y}}$ & $100.00^{a}{ }_{x}$ & - \\
\hline No water & $35.32^{\mathrm{b}}$ & $16.25^{\mathrm{b}}$ & $56.45^{a}{ }_{x}^{a}$ & $22.22^{\mathrm{b}} \mathrm{z}$ & $0.00^{\mathrm{c}} \mathrm{y}$ \\
\hline \multirow[t]{2}{*}{ Control } & $49.79^{\mathrm{ab}}$ & $32.09^{b}$ & $60.29^{\mathrm{a}}{ }_{x}$ & $58.21_{\mathrm{y}}^{\mathrm{a}}$ & $41.35^{a b}{ }_{x}$ \\
\hline & 1 & 3 & 6 & 10 & 15 \\
\hline \multicolumn{6}{|c|}{ Herbicide experiment } \\
\hline Paraquat & $76.71_{\mathrm{x}}$ & $89.47_{\mathrm{x}}$ & $100.00_{x}$ & - & - \\
\hline Glyphosate & $50.35 \mathrm{y}$ & $30.72 \mathrm{y}$ & $53.85_{\mathrm{y}}$ & $66.67 \mathrm{x}$ & 50.00 \\
\hline Control & $40.77_{\mathrm{y}}$ & $35.08_{\mathrm{y}}^{\mathrm{y}}$ & $26.59 \mathrm{y}$ & $35.78_{\mathrm{y}}$ & 34.87 \\
\hline
\end{tabular}

${ }^{\mathrm{z}}$ Within each experiment, superscripts $\mathrm{a}, \mathrm{b}$, or $\mathrm{c}$ indicate means in a row (time course within a treatment) that group separately $(P<0.05)$ following an analysis of variance; within each experiment, subscripts $\mathrm{x}, \mathrm{y}$, and $\mathrm{z}$ indicate means that group separately in a column (comparison of treatment effects at a time point). If there were no significant differences in a row or column, the super- or subscripts are not shown. 
pared with the control, but this effect was not consistent (Table 5). In the herbicide experiment, the percentage of WCM on the upper half of the leaf was consistently lower for the paraquat treatment compared with the control (Table 5). Glyphosate did not have an effect on the estimated percentage until the fifteenth day, when there were too few mites to yield a good estimate (Table 5).

Percentage of WCM on outside of leaves. The percentage of living WCM on the outside of leaves rarely underwent significant changes in the three experiments, only showing a slight increase toward the middle of the sampling period in the second experiment (Table 6). Stem cutting and withholding water sometimes affected the percentage on the outside in the second experiment, but estimated percentages changed rapidly during the sample dates, especially toward the end of the experiment when there were few WCM present from which to estimate the percentage (Table 6). In the herbicide experiment, treatment with paraquat increased the percentage on the outside compared with the control only on the first day after treatment, and glyphosate did not have a significant effect (Table 6).

Total green leaf area in response to herbicide treatments. The total green leaf area (TGLA) of the three youngest leaves on plants without WCM and WSMV was higher from the beginning of the sampling period (Fig. 2). The glyphosate treatment

Table 4. Mean percentage of living wheat curl mites in an upright posture over time in two tillagedrought experiments and one herbicide experiment ${ }^{2}$

\begin{tabular}{|c|c|c|c|c|c|}
\hline \multirow[b]{2}{*}{ Treatment } & \multicolumn{5}{|c|}{ Days after treatment } \\
\hline & 1 & 2 & 3 & 5 & 7 \\
\hline \multicolumn{6}{|c|}{ First tillage-drought experiment } \\
\hline Stem cutting & $21.21^{\mathrm{b}} \mathrm{x}$ & $17.03^{c}{ }_{x}$ & $10.81^{\mathrm{c}}$ & $75.00^{\mathrm{a}} \mathrm{x}$ & - \\
\hline No water & $15.02^{\mathrm{a}} \mathrm{ay}^{\mathrm{a}}$ & $14.94^{\mathrm{ab}}{ }_{\mathrm{xy}}$ & $5.14^{\mathrm{b}}$ & $3.57^{\mathrm{b}} \mathrm{y}$ & $5.53^{b}$ \\
\hline \multirow[t]{2}{*}{ Control } & $10.39 y^{\mathrm{xy}}$ & $7.26_{y}$ & 10.62 & $8.85_{y}$ & 6.53 \\
\hline & 1 & 3 & 6 & 10 & 15 \\
\hline \multicolumn{6}{|c|}{ Second tillage-drought experiment } \\
\hline Stem cutting & $13.37^{\mathrm{b}}$ & $42.42^{b}{ }_{x}$ & $100.00^{\mathrm{a}}{ }_{\mathrm{x}}$ & $100.00^{\mathrm{a}} \mathrm{x}$ & - \\
\hline No water & $9.64^{\mathrm{b}}$ & $5.00^{\mathrm{b}}$ & $8.72^{\mathrm{b}}{ }_{\mathrm{z}}$ & $77.78^{a}{ }_{y}$ & $0.00^{\mathrm{c}}$ \\
\hline \multirow[t]{2}{*}{ Control } & $10.79^{\mathrm{b}}$ & $7.98^{c^{y}}$ & $15.57_{y}^{\mathrm{a}}$ & $11.14^{\mathrm{b}} \mathrm{z}$ & $19.01^{\mathrm{a}}$ \\
\hline & 1 & 3 & 6 & 10 & 15 \\
\hline \multicolumn{6}{|c|}{ Herbicide experiment } \\
\hline Paraquat & 2.91 & 3.71 & 10.00 & - & - \\
\hline Glyphosate & 1.93 & 2.12 & 5.33 & 40.66 & 50.00 \\
\hline Control & 9.48 & 4.70 & 3.35 & 3.62 & 5.39 \\
\hline
\end{tabular}

${ }^{\mathrm{z}}$ Within each experiment, superscripts $\mathrm{a}, \mathrm{b}$, or $\mathrm{c}$ indicate means in a row (time course within a treatment) that group separately $(P<0.05)$ following an analysis of variance; within each experiment, subscripts $\mathrm{x}, \mathrm{y}$, and $\mathrm{z}$ indicate means that group separately in a column (comparison of treatment effects at a time point). If there were no significant differences in a row or column, the super- or subscripts are not shown.

Table 5. Mean percentage of living wheat curl mites on the upper half of the leaves (toward the leaf tip) over time in two tillage-drought experiments and one herbicide experiment ${ }^{\mathrm{Z}}$

\begin{tabular}{|c|c|c|c|c|c|}
\hline \multirow[b]{2}{*}{ Treatment } & \multicolumn{5}{|c|}{ Days after treatment } \\
\hline & 1 & 2 & 3 & 5 & 7 \\
\hline \multicolumn{6}{|c|}{ First tillage-drought experiment } \\
\hline Stem cutting & $22.56_{y}$ & $28.15_{\mathrm{y}}$ & $20.64_{y}$ & $29.17 \mathrm{y}$ & - \\
\hline No water & $64.00^{\mathrm{a}}{ }_{x}$ & $42.48^{\mathrm{bc}}{ }_{x}$ & $32.31^{\mathrm{c}}{ }_{\mathrm{y}}$ & $48.26^{\mathrm{b}}{ }_{\mathrm{x}}$ & $31.86^{\mathrm{c}}$ \\
\hline \multirow[t]{2}{*}{ Control } & $32.89_{\mathrm{y}}$ & $51.48_{\mathrm{x}}$ & $51.33_{\mathrm{x}}^{\mathrm{y}}$ & $33.41_{x y}^{x}$ & 49.97 \\
\hline & 1 & 3 & 6 & 10 & 15 \\
\hline \multicolumn{6}{|c|}{ Second tillage-drought experiment } \\
\hline Stem cutting & $31.22^{\mathrm{b}}$ & $12.12^{\mathrm{bc}}$ & $100.00^{\mathrm{a}} \mathrm{x}$ & $0.00^{c} \mathrm{z}$ & - \\
\hline No water & $40.80^{\mathrm{ab}}$ & $22.55^{\mathrm{bc}}$ & $17.16^{\mathrm{c}}$ & $55.56^{a^{\mathrm{a}}}$ & $100.00^{\mathrm{a}}$ \\
\hline \multirow[t]{2}{*}{ Control } & 32.57 & 30.69 & $20.66_{y}^{y}$ & $32.71_{\mathrm{y}}$ & 44.85 \\
\hline & 1 & 3 & 6 & 10 & 15 \\
\hline \multicolumn{6}{|c|}{ Herbicide experiment } \\
\hline Paraquat & $23.16_{y}$ & $25.65_{\mathrm{y}}$ & $20.00_{\mathrm{y}}$ & - & - \\
\hline Glyphosate & $44.00^{\mathrm{a}}{ }_{\mathrm{x}}$ & $46.62^{\mathrm{a}}{ }_{x y}$ & $29.20^{\mathrm{ab}}{ }_{\mathrm{xy}}$ & $38.46^{\mathrm{ab}}$ & $0.00_{\mathrm{y}}^{\mathrm{b}}$ \\
\hline Control & $52.97^{\wedge}$ & $50.96_{x}$ & $40.43_{x}$ & 34.73 & $39.46_{x}$ \\
\hline
\end{tabular}

${ }^{\mathrm{z}}$ Within each experiment, superscripts $\mathrm{a}, \mathrm{b}$, or $\mathrm{c}$ indicate means in a row (time course within a treatment) that group separately $(P<0.05)$ following an analysis of variance; within each experiment, subscripts $\mathrm{x}, \mathrm{y}$, and $\mathrm{z}$ indicate means that group separately in a column (comparison of treatment effects at a time point). If there were no significant differences in a row or column, the super- or subscripts are not shown. significantly reduced TGLA compared with the control by the sixth day after treatment, while the TGLA of infected plants was significantly reduced by the tenth day (Fig. 2). The effect of paraquat on TGLA was more rapid than for glyphosate and showed a similar pattern for both infected and WCM-free plants (Fig. 2 ). Both the TGLA and the WCM population started to decrease on day 6 for the glyphosate treatment (Figs. 1 and 2). In most cases, those plants with a higher TGLA had higher numbers of living WCM $(P<0.0001, r=0.90)$.

\section{DISCUSSION}

WCM survival after treatment applications varied substantially for the different treatments evaluated. Paraquat application and stem cutting both acted to rapidly reduce mite populations, with effects apparent within a few days of application. Glyphosate application and withholding water had slower effects. These results are consistent with the recent finding of Thomas et al. (32) that tillage was more effective than glyphosate treatment for reducing spread of WSMV from volunteer wheat in the field. Although glyphosate prolongs WCM retention compared with paraquat and tillage, glyphosate may still be the best choice for management of volunteer wheat because of its broad spectrum weed control, cost effectiveness, and probable lower toxicity to the applicator and other animal and plant species (20). But when glyphosate is used for volunteer wheat control, greater caution must be taken to ensure that it is applied long enough before newly planted wheat emerges and may become infested with WCM. The window of risk may also vary due to environmental conditions. Herbicide activity is more rapid when plants are actively growing, so drought conditions may delay herbicide effects (20). The effect of undercutting in the field might be somewhere between the effects of withholding water and stem cutting in these experiments. Undercutting would tend to leave some amount of root tissue, which would allow the plants to survive longer than would stem cutting, but for a shorter period of time than would the beginning of a drought. WCM may survive briefly after leaving plants, and their survival time will also be a function of environmental conditions.

Mites were designated as "living" in our study based on their movement and color. Some mites still on plants did not appear to be alive, often exhibiting extreme states of desiccation. Designation based on movement and color may underestimate the total living population. WCM show little or no movement when they feed or molt. Feeding WCM may move if prodded, but molting WCM cannot move (30). However, comparisons between treatments should still be accurate. WCM may be negatively phototactic $(5,18)$, even under 
favorable conditions, and did tend to try to move out of the light when leaves were being examined under the dissecting microscope. The percent WCM that were living may have resulted from at least two different processes. First, living WCM may leave plants when the quality of food provided by the plant diminishes; second, dead WCM may fall from plants. In any case, mites that are no longer associated with plants will not survive long (26).

We were also interested in whether WCM responding to stress moved to a position ready to be carried away by wind, such as positioning in an upright posture, on the outer part of leaves, on the upper half of leaves, or on the uppermost leaf. Some previous studies have reported such movement in response to stress or overcrowding of mites $(8,18)$. However, Thomas and Hein (31) reported that mite population size was a more important factor in determining mite movement from plants than plant condition; in fact, they concluded that stressed plants were less important sources of WCM simply because their WCM populations were lower. When WCM populations were declining in response to treatments in our experiments, WCM were sometimes more likely to assume an upright posture, but the presence of WCM with an upright posture did not appear to serve as an early warning for potential WCM emigration. Effects appeared somewhat erratic, probably at least in part because when stress was greatest, only a small number of WCM were present to provide estimates. The position of mites on different plant parts could be more a function of which plant parts survive as a food source longest in addition to potential movement of WCM. The tendency for living WCM on plants treated with paraquat to be more common on the third leaf might have resulted because green tissue was limited to the youngest leaf rather than because of movement to that leaf; small islands of green tissue were sometimes observed on paraquat-treated plants. The upper half of leaves was not necessarily a better potential launching position because of leaf-trapping that bent the leaves downward. An upright posture may be more indicative of intended emigration. Handling of the leaves may have affected WCM posture, but relative comparisons between treatments are probably still valid, particularly when there were enough WCM present for good estimates of percentages. Stem cutting seemed to result in increases in WCM in upright postures, as did glyphosate treatment in the later days of the experiment. It should also be noted that plants in these experiments were almost always in a wind-still environment, while Nault and Styer (18) have observed that the air movement over the leaf surface may have stimulated perpendicular standing and chain formation in WCM. High wind speeds common in wheat growing areas such as the Great Plains might have elicited different reactions from the WCM.

While the effect of paraquat on TGLA was similar for both infected and WCMfree plants, it appeared that glyphosate had a more rapid effect on TGLA for WCMfree plants (Fig. 2). If this effect is consistent in the field, then information about infection of volunteer wheat may be useful for determining risks of volunteer management strategies. The window of risk following glyphosate treatment might be shorter for plants newly infested by WCM and infected by WSMV than for plants with established viruliferous WCM populations. Nonviruliferous WCM populations also can produce important effects on plant growth through longitudinal leaf rolling, stunting, necrosis, and even plant death (12), which may influence plant responses to glyphosate treatment. However, our study did not partition WCM effects from those of WSMV.

The strong relationship between TGLA and the number of mites suggests that the amount of green tissue present in volunteer wheat may be a good indicator of the potential for emigration of the WCM and WSMV. If this relationship is consistent in field populations of volunteer wheat, it could be used to predict whether fields with managed volunteer wheat still present a risk of emigration.

Table 6. Mean percentage of living wheat curl mites on the outside of leaves, as opposed to inside the curled leaves, in three experiments ${ }^{\mathrm{z}}$

\begin{tabular}{lccccc}
\hline & \multicolumn{5}{c}{ Days after treatment } \\
\cline { 2 - 6 } Treatment & $\mathbf{1}$ & $\mathbf{2}$ & $\mathbf{3}$ & $\mathbf{5}$ & $\mathbf{7}$ \\
\hline First tillage-drought experiment & & & & \\
Stem cutting & 4.07 & 7.94 & 9.96 & 12.50 & - \\
No water & 5.00 & 11.85 & 9.26 & 7.82 & 9.79 \\
Control & 4.87 & 8.13 & 12.39 & 13.06 & 11.20 \\
\hline \multicolumn{7}{c}{} & $\mathbf{3}$ & $\mathbf{6}$ & $\mathbf{1 0}$ & $\mathbf{1 5}$ \\
\hline Second tillage-drought experiment & & & & \\
Stem cutting & $5.88^{\mathrm{c}}$ & $6.06^{\mathrm{b}}{ }_{\mathrm{y}}$ & $0.00^{\mathrm{c}}{ }_{\mathrm{y}}$ & $100.0^{\mathrm{a}}{ }_{\mathrm{x}}$ & - \\
No water & $11.15^{\mathrm{b}}$ & $8.27^{\mathrm{b}} \mathrm{xy}$ & $7.08^{\mathrm{b}}$ & $77.78^{\mathrm{a}} \mathrm{y}$ & $0.00^{\mathrm{c}} \mathrm{y}$ \\
Control & $9.05^{\mathrm{b}}$ & $8.83^{\mathrm{b}}{ }_{\mathrm{x}}$ & $12.83^{\mathrm{ab}}{ }_{\mathrm{x}}$ & $18.82^{\mathrm{a}}{ }_{\mathrm{z}}$ & $6.73^{\mathrm{b}}{ }_{\mathrm{x}}$ \\
\hline \multicolumn{7}{c}{} & $\mathbf{3}$ & $\mathbf{6}$ & $\mathbf{1 0}$ & $\mathbf{1 5}$ \\
\hline Herbicide experiment & $\mathbf{1}$ & & & & \\
Paraquat & $27.53^{\mathrm{a}}{ }_{\mathrm{x}}$ & $3.43^{\mathrm{b}}$ & $10.00^{\mathrm{ab}}$ & - & - \\
Glyphosate & $5.80_{\mathrm{y}}$ & 9.45 & 14.48 & 61.54 & 0.00 \\
Control & $7.51_{\mathrm{y}}$ & 13.52 & 15.73 & 13.47 & 6.88 \\
\hline
\end{tabular}

${ }^{\mathrm{z}}$ Within each experiment, superscripts $\mathrm{a}, \mathrm{b}$, or $\mathrm{c}$ indicate means in a row (time course within a treatment) that group separately $(P<0.05)$ following an analysis of variance; within each experiment, subscripts $\mathrm{x}, \mathrm{y}$, and $\mathrm{z}$ indicate means that group separately in a column (comparison of treatment effects at a time point). If there were no significant differences in a row or column, the super- or subscripts are not shown.

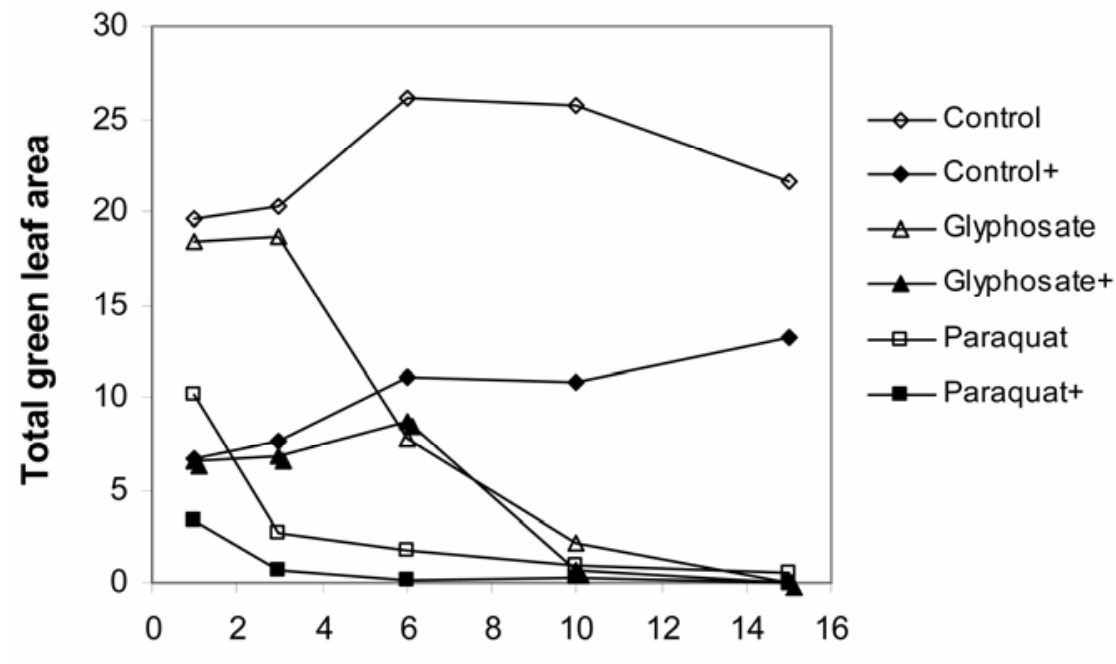

Days after treatments

Fig. 2. Total green leaf area $\left(\mathrm{cm}^{2}\right)$ of the three youngest leaves over time in response to wheat curl mite infestation/wheat streak mosaic virus infection (indicated by +) and herbicide treatments. New leaves were generally not produced by infected plants. 
While timely removal of volunteer wheat can reduce the risk of WSMV movement to wheat planted in fall, the practice may have a cost. Summer tillage can increase erosion and soil moisture loss, and also may result in smaller populations of wildlife such as pheasant that support hunting as an alternative rural income source $(21,22)$. Summer herbicide application generally results in less soil erosion and moisture loss, but still may impact wildlife populations by decreasing food sources.

The development of complete risk assessments for field scenarios is complicated by the great importance of weather variables for the development of WSMV and WCM populations. Weather conditions will determine whether one WCM per volunteer wheat plant, evaluated as a lowrisk population size in our experiments, is a sufficient number to initiate an epidemic in neighboring newly sown wheat fields. Pady (19) reported trapping WCM at a height of 152 feet $(46.3 \mathrm{~m})$ and 1.5 to 2 miles ( 2.4 to $3.2 \mathrm{~km}$ ) from the nearest wheat field, so there is also the potential for long-distance movement. Highly conducive conditions for WCM survival in transit and for reproduction of WCM when deposited on new wheat plants could allow an important epidemic to begin from very small numbers of viruliferous mites. Nonconducive conditions when wheat emerges in fall could result in low risk of infection even with higher WCM populations on volunteer wheat.

Another factor complicating risk analysis is the broad host range of the WCM and WSMV. The WCM host range includes corn, barley, rye, oats, sorghum, pearl millet, and many annual and perennial wild grasses $(2-4,13,14,18,24-30)$. Severe epidemics of WSM have occurred when little volunteer wheat is present (35). Minor hosts of WCM and WSMV could function as another green bridge between earlier availability of summer volunteer wheat and newly sown wheat in fall.

The WCM represents an example of a disease vector that can survive for only a short time in the absence of a living plant host. Wheat management strategies will have a somewhat different effect on the window of risk for transmission of other wheat pathogens and pests. For example, the wheat take-all pathogen can survive for limited periods of time in dead wheat crowns in no-till systems (34), but the presence of volunteer wheat may help support larger and more robust pathogen populations. For evaluation of risk, it would also be useful to know whether other pathogens or insect pests modify volunteer wheat physiology such that the rate of herbicide action on plants, and thus WCM, is affected.

\section{ACKNOWLEDGMENTS}

We thank S. P. Dendy, J. Pierzynski, and Z. Su for their help with these experiments and L. Hagen, T. J. Martin, D. Seifers, J. Stack, and Plant Disease reviewers for comments that improved this manuscript. Support for this project was provided by USDA grant 2002-34103-11746. This is Kansas State Experiment Station Contribution No. 05-121-J.

\section{LITERATURE CITED}

1. Bowden, R. L., Brooks, H. L., Peterson, D. E., and Shroyer, J. P. 1991. Be a good neighbor: Control your volunteer wheat. 1991. Kans. State Univ. Agric. Exp. Stn. Coop. Ext. Serv. MF-1004.

2. Brey, C. W., Johnson, G. D., and Blodgett, S. L. 1998. Survey of Montana grasses for wheat curl mite (Acari: Eriophyidae), the vector of wheat streak mosaic virus. J. Agric. Entomol. 15:173-180.

3. Christian, M. L., and Willis, W. G. 1993. Survival of wheat streak mosaic virus in grass hosts in Kansas from wheat harvest to fall wheat emergence. Plant Dis. 77:239-242.

4. Connin, R. V. 1956. The host range of the wheat curl mite, vector of wheat streak mosaic. J. Econ. Entomol. 49:1-4.

5. del Rosario, M. S., and Sill, W. H., Jr. 1958. A method of rearing large colonies of an eriophyid mite, Aceria tulipae (Keifer) in pure culture from single eggs or adults. J. Econ. Entomol. 51:303-306.

6. Franz, J. E., Sikorski, J. A., and Mao, M. K. 1997. Glyphosate: A Unique Global Herbicide. American Chemical Society, Washington, DC.

7. Garrett, K. A., Madden, L. V., Hughes, G., and Pfender, W. F. 2004. New applications of statistical tools in plant pathology. Phytopathology 94:999-1003.

8. Gibson, W. D., and Painter, R. H. 1957. Transportation by aphids of the wheat curl mite, Aceria tulipae (K.), a vector of wheat streak mosaic virus. J. Kans. Entomol. Soc. 30:147152.

9. Gottwald, T. R., Hughes, G., Graham, J. H., Sun, X., and Riley, T. 2001. The citrus canker epidemic in Florida: The scientific basis of regulatory eradication policy for an invasive species. Phytopathology 91:30-34

10. Graham, J. H., and Gottwald, T. R. 1991. Research perspectives on eradication of citrus bacterial diseases in Florida. Plant Dis. 75:1193-1200.

11. Harvey, T. L., Martin, T. J., and Seifers, D. L. 1995. Survival of five wheat curl mite, Aceria tosichilla Keifer (Acari: Eriophyidae), strains on mite resistant wheat. Exp. Appl. Acar. 19:459-463.

12. Harvey, T. L., Martin, T. J., and Seifers, D. L. 2000. Effect of nonviruliferous wheat curl mite on yield of winter wheat. J. Agric. Entomol. 17:9-13.

13. Harvey, T. L., and Seifers, D. L. 1991. Transmission of wheat streak mosaic virus to sorghum by the wheat curl mite (Acari: Eriophyidae). J. Kans. Entomol. Soc. 64:18-22.

14. Harvey, T. L., Seifers, D. L., and Martin, T. J. 2001. Host range differences between two strains of wheat curl mite (Acari: Eriophyidae). J. Agric. Urban Entomol. 18:35-41.

15. Harvey, T. L., Seifers, D. L., Martin, T. J., Brown-Guedira, G., and Gill, B. S. 1999. Survival of wheat curl mite on different sources of resistance in wheat. Crop Sci. 39:1887-1889.

16. Kearney, P. C., and Kaufman, D. D. 1975. Herbicides: Chemistry, Degradation, and Mode of Action. 2nd ed. M. Dekker, New York.

17. Littell, R. C., Milliken, G. A., Stroup, W. W., and Wolfinger, R. D. 1996. SAS System for Mixed Models. SAS Institute, Cary, NC.

18. Nault, L. R., and Styer, W. E. 1969. The dispersal of Aceria tulipae and three other grassinfesting Eriophyid mites in Ohio. Ann. Entomol. Soc. Am. 62:1446-1455.

19. Pady, S. M. 1955. The occurrence of the vector of wheat streak mosaic, Aceria tulipae, on slides exposed in the air. Plant Dis. Rep. 39:296-297.

20. Peterson, D. E., Thompson, C. R., Regehr, D. L., and Al-Khatib, K. 2001. Herbicide mode of action. Kans. State Univ. Agric. Exp. Stn. Coop. Ext. Serv. C-715.

21. Rodgers, R. D. 1994. Effects of various forms of wheat stubble management on wildlife. Pages 187-194 in: Proc. Great Plains Residue Manag. Conf., Great Plains Agric. Council Bull. No. 150.

22. Rodgers, R. D. 1999. Why haven't pheasant populations in western Kansas increased with CRP? Wildlife Soc. Bull. 27:654-665.

23. Roelfs, A. P. 1982. Effects of barberry eradication on stem rust in the United States. Plant Dis. 66:177-181.

24. Seifers, D. L., Harvey, T. L., Kofoid, K. D. and Stegmeier, W. D. 1996. Natural infection of pearl millet and sorghum by wheat streak mosaic virus in Kansas. Plant Dis. 80:179-185.

25. Seifers, D. L., Harvey, T. L., Martin, T. J., and Jensen, S. G. 1998. A partial host range of the High Plains virus of corn and wheat. Plant Dis. 82:875-879.

26. Slykhuis, J. T. 1955. Aceria tulipae Keifer (Acarina: Eriophyidae) in relation to the spread of wheat streak mosaic. Phytopathology 45:116-128.

27. Slykhuis, J. T. 1963. Mite transmission of plant viruses. Adv. Acarol. 1:326-340.

28. Slykhuis, J. T. 1965. Mite transmission of plant viruses. Adv. Virus Res. 11:97-137.

29. Somsen, H. W., and Sill, W. H. 1970. The wheat curl mite, Aceria tulipae Keifer, in relation to epidemiology and control of wheat streak mosaic. Agric. Exp. Stn. Res. Publ. 102.

30. Staples, R., and Allington, W. B. 1956. Streak mosaic of wheat in Nebraska and its control. Univ. Nebr., Lincoln. Agric. Exp. Stn. Res. Bull. 178.

31. Thomas, J. A., and Hein, G. L. 2003. Influence of volunteer wheat plant condition on movement of the wheat curl mite, Aceria tosichella, in winter wheat. Exp. Appl. Acarol. 31:253-268.

32. Thomas, J. A., Hein, G. L., and Lyon, D. J. 2004. Spread of wheat curl mite and wheat streak mosaic virus is influenced by volunteer wheat control methods. Online. Plant Health Progress DOI:10.1094/PHP-2004-1206-01-RS.

33. Watkins, J. E., French, R. C., Campbell, J. B., Kerr, E. D., and Klein, R. N. 1989. Wheat streak mosaic disease. Univ. Nebr. Coop. Ext. EC89-1871.

34. Wilkinson, H. T., Cook, R. J., and Alldredge, J. R. 1985. Relation of inoculum size and concentration to infection of wheat roots by Gaeumannomyces graminis var. tritici. Phytopathology 75:98-103.

35. Willis, W. G. 1981. The 1981 wheat streak mosaic epidemic in Kansas. Coop. Ext. Rep. Kans. State Univ., Manhattan.

36. Zar, J. H. 1984. Biostatistical Analysis. Prentice-Hall, Englewood Cliffs, NJ. 